Review

\title{
Perspectives of Breast Cancer Thermotherapies
}

\author{
Edouard Alphandéry ${ }^{1,2}$ \\ 1. Nanobacterie SARL, 36 boulevard Flandrin, 75116, Paris, France. \\ 2. Institut de Minéralogie et de Physique des Milieux Condensés, Université Pierre et Marie Curie, 4 Place Jussieu, 75005, Paris, France.
}

$\bowtie$ Corresponding author: Edouard Alphandéry, E-mail: edouardalphandery@hotmail.com Mobile: 0033(0)632697020.

(C) Ivyspring International Publisher. This is an open-access article distributed under the terms of the Creative Commons License (http://creativecommons.org/ licenses/by-nc-nd/3.0/). Reproduction is permitted for personal, noncommercial use, provided that the article is in whole, unmodified, and properly cited.

Received: 20I4.0I.27; Accepted: 20I4.05.08; Published: 20I4.05.29

\begin{abstract}
In this article, the use of different types of thermotherapies to treat breast cancer is reviewed. While hyperthermia is most commonly used as an adjuvant in combination with radiotherapy, chemotherapy, targeted therapy or cryotherapy to enhance the therapeutic effect of these therapies, thermoablation is usually carried out alone to eradicate small breast tumors. A recently developed thermotherapy, called magnetic hyperthermia, which involves localized heating of nanoparticles under the application of an alternating magnetic field, is also presented. The advantages and drawbacks of these different thermotherapies are highlighted.
\end{abstract}

Key words: breast cancer, thermotherapies

\section{Introduction}

Breast cancer $(\mathrm{BC})$ is a malignant tumor that originates from healthy mammary gland cells. The most common type of $\mathrm{BC}$ is a carcinoma originating from glandular tissues. BC is most frequent among women aged between 50 and 70, (1-3). It affects one in eight women on average and is the most common type of cancer among women, (1-3). About one million new cases of BC are diagnosed each year worldwide, representing about a third of new cases of all female cancers in industrialized countries and $15 \%$ of new cases in developing countries. With the improvement of treatments, the survival rate of women diagnosed with $\mathrm{BC}$ has increased by $2 \%$ a year during the last twenty years, (1-3). However, despite this improvement, the mortality due to $\mathrm{BC}$ remains significant among women with about 20 women over 100000 dying from this disease each year worldwide, (1-3). The mortality rate of $\mathrm{BC}$ depends on its stage. While BC stages I (localized tumors of less than $2 \mathrm{~cm}$ ) and II (tumors of 2 to $5 \mathrm{~cm}$ without nodes) can be cured relatively simply using surgery resulting in a mortality rate of less than $50 \%$, those of grades III (infiltrating tumors without metastases) and IV (presence of metastases) are much harder to treat, usually require heavy treatments often involving a combination of surgery, chemotherapy and radiotherapy, and result in a mortality rate of more than $50 \%$, (1-3).

There are essentially three different ways to decrease the mortality rate of BC. Firstly, BC arises because of several risks factors, such as aging, disease (hyperplasia), a diet with a high intake of saturated fat, overweight, excessive alcohol consumption, exposure to ionizing radiation, the consumption of oral contraceptives, hormone replacement therapy, (1-3). The first method, which can result in a decrease in the BC mortality rate, lies in the control of these risk factors, for example by making the women way of life healthier. Secondly, the BC mortality rate can be decreased by improving BC diagnosis, (1-3). The latter needs to be carried out frequently, accurately and early enough, i. e. possibly before stages III and IV of $\mathrm{BC}$ have been reached. Screening for BC can be carried out in three different ways. The first method involves self-examination of the breast. It yields controversial results due to the difficulty for the women to detect a tumor by themselves. Instead, it is usually recommended that women should consult a trained doctor who carries out a clinical exam to detect a tumor inside the breast. The main and most reliable technique 
used for BC detection is mammography. With this technique, an image of the inside of the breast is obtained using $\mathrm{X}$-rays and breast abnormalities are looked for. In the United States, $70 \%$ of women above 40 years old have had a mammography during the last two years, (4). One of the main problems with mammography is the significant percentage of overdiagnosis $(\sim 10 \%)$, (5), which leads women to be diagnosed with BC and treated whereas their condition is not life threatening and in some cases will never cause any symptoms. The third way to decrease BC mortality consists in improving BC treatments. For that, thermotherapy can be used. This type of therapy is scarcely used despite its efficacy. Indeed, it has shown its efficacy, specifically for treatments of BC of stages III and IV for which the mortality rate is high and efficient treatments are lacking. The purpose of this review is to highlight the positive impacts as well as drawbacks of three different types of thermotherapies, hyperthermia, thermoablation and magnetic hyperthermia for $\mathrm{BC}$ treatment. (General information regarding the different types of thermotherapies is provided in table 1; The advantages of magnetic hyperthermia compared with other types of thermotherapies are summarized in table 2).

\section{Treatments commonly used to treat breast cancer}

The treatments commonly used to treat BC are first presented, (1-3). Surgery is usually divided into conservative surgery, which results in the removal of the tumor without that of the entire breast, usually designated as lumpectomy or partial mastectomy, and "non conservative" surgery, usually designated as total mastectomy, which involves heavier surgery with the removal of the whole breast. There is a need to develop new techniques that can replace total mastectomy, which is used in $30 \%$ of all BC surgeries, (1-3), essentially to limit the risk of metastases, to preserve woman breasts.

Radiotherapy (also called radiation therapy) is commonly used for patients that have either previously been treated with conservative surgery or possess metastases or lymph nodes that appear at an advanced stage of BC (typically stage III or IV), (1-3). Two different types of radiotherapy can be carried out, external radiotherapy, which uses a generator that directs high energy radiations (X-rays, gamma rays or electrons) towards the breast tumor or brachytherapy, in which the radiation is generated using a radioactive material introduced inside the breast. Briefly, the mechanism of tumor destruction by radiations involves the ionization of biological tissues, generating free radicals, which interact with biological material, cells and DNA and yield tumor cell death. Despite of the improvement of radiation therapy, for example with the development of the intrabeam equipment, (6), or mammosite, (7), a critical issue remains to be addressed: the possibility of the destruction of BC cells without inducing toxicity for healthy tissues. A therapeutic window has been identified, which corresponds to an exposure of the patient to a radiation dose of 60 to $80 \mathrm{~Gy}$, (1-3). Although such doses result in the destruction of cancer cells with a relatively high probability of 40 to $100 \%$, they do not completely prevent undesirable side effects that can occur with a probability of 20 to $90 \%$, (1-3). In order to minimize these side effects, lower doses of radiation are required, which can be obtained by sensitizing the tumor cells, using for example hyperthermia, (8).

In chemotherapy, drugs, which are usually administered intravenously to act on the whole body, are either used to prevent the development of metastasis or to reduce tumor sizes. The main drawback of chemotherapy is due to the nonspecific targeting of tumor cells, which results in side effects such as hair losses or women overweight.

Hormone therapy works by reducing the activity of female hormones, estrogen and progesterone, which stimulate the growth of hormone sensitive tumors contained in $80 \%$ of women diagnosed with BC, (1-3). Hormone therapies either use drugs, X-rays or surgery to stop the production of female hormones by the ovaries. As for chemotherapy, it can cause a number of side effects such as menopause, osteoporosis or hair losses.

Targeted therapy combined with immunotherapy, (9), is used to treat BC that overexpresses the HER-2 (human epidermal growth factor receptor 2) gene, which promotes the growth of BC cells. Drugs such as Herceptin (Trastuzumab), which is an antibody, specifically target HER-2 and destroy the BC cells overexpressing HER-2 through the stimulation of the immune system, (10). HER-2 is however overexpressed only in a limited percentage of women $(20 \%)$, restricting the use of this therapy to only a portion of the women diagnosed with $\mathrm{BC},(1-3)$.

Triple negative BCs that represent $\sim 20 \%$ of all BC cases do not express HER-2 and grow without the support of the hormones estrogen and progesterone. They can't therefore be treated with hormone therapy or Herceptin.

Cryotherapy, also called cryosurgery, uses extreme cold to freeze the water present in BC cells. Water, turned to ice crystals, along with the cold itself, destroys the cancer cells. It is too early to make conclusions regarding the efficacy of cryotherapy, since many of the results of studies involving this approach are still pending, (11). 
Finally, two reasons for the development of new $\mathrm{BC}$ therapies such as thermotherapies can be underlined:

- $\mathrm{BC}$ is the most important cancer among women,
- For indications such as local regional breast cancer recurrence, the treatments described above are inefficient and $\mathrm{BC}$ often results in the death of the patient.

Table I. Summary of the physical mechanisms, procedures, preclinical and clinical data available for each type of thermotherapy described in this review.

\begin{tabular}{|c|c|c|c|c|}
\hline Methods & Physical mechanisme & Procedures & $\begin{array}{c}\text { Examples of } \\
\text { pre-clinical trials }\end{array}$ & $\begin{array}{l}\text { Examples of } \\
\text { clinical trials }\end{array}$ \\
\hline $\begin{array}{l}\text { Microwaves } \\
\text { Hyperthermia }\end{array}$ & $\begin{array}{l}\text { Microwave energy is } \\
\text { transferred into heat } \\
\text { inside the tumor. }\end{array}$ & $\begin{array}{l}\text { Microwaves antennas are positioned } \\
\text { near the tumor. The amount of heat } \\
\text { generated is less than } 43^{\circ} \mathrm{C}\end{array}$ & $\begin{array}{l}\text { Recently developped } \\
\text { focused microwave } \\
\text { thermal therapy of the } \\
\text { breast with a } 1.5 \mathrm{~cm} \\
\text { diameter focal spot size, } \\
\text { [66]. }\end{array}$ & $\begin{array}{c}\text { Trial NCT00036985 } \\
\text { Combination of chemotherapy } \\
\text { with microwave thermotherapy } \\
\text { before surgery to treat women } \\
\text { with locally advanced breast } \\
\text { cancer. }\end{array}$ \\
\hline $\begin{array}{l}\text { Far infra-red } \\
\text { radiations } \\
\text { Hyperthermia }\end{array}$ & $\begin{array}{l}\text { Electromagnetic heating } \\
\text { induced by waves of } \\
\text { wavelengths between } 4 \\
\text { and } 1000 \mu \mathrm{m} .\end{array}$ & $\begin{array}{l}\text { The whole body is heated by FIR light } \\
\text { to } 40^{\circ} \mathrm{C} \text { during } 20 \text { min several times a } \\
\text { week. }\end{array}$ & $\begin{array}{l}\text { Inhibition by whole-body } \\
\text { hyperthermia with far- } \\
\text { infrared rays of the growth } \\
\text { of spontaneous mammary } \\
\text { tumours in mice, [69]. }\end{array}$ & $\begin{array}{l}\text { Trial NCT00574106 } \\
\text { A study to evaluate the effect of far } \\
\text { infrared radiation for cancer } \\
\text { treatment. }\end{array}$ \\
\hline $\begin{array}{l}\text { Radiofrequencies } \\
\text { ablation (RFA) } \\
\text { Thermoablation }\end{array}$ & $\begin{array}{l}\text { Electrical conduction } \\
\text { system of the tumor is } \\
\text { ablated using the heat } \\
\text { generated by a high } \\
\text { frequency alternating } \\
\text { current ( } 350-500 \mathrm{kHz} \text { ) }\end{array}$ & $\begin{array}{l}\text { RFA probe positioned inside the tumor } \\
\text { to generate radiofrequencies waves, } \\
\text { which heat and subsequently destroy } \\
\text { breast tumors. }\end{array}$ & $\begin{array}{l}\text { A review on the general } \\
\text { aspects of radiofrequency } \\
\text { ablation gives examples of } \\
\text { preclinical trials, [70]. }\end{array}$ & $\begin{array}{c}\text { Treatment of patients with breast } \\
\text { cancer by radiofrequency } \\
\text { thermoablation in locally advanced } \\
\text { breast cancer, }[67,68] \text {. } \\
\text { Complete regression of breast } \\
\text { tumor in } 10 \% \text { of patients with } \\
\text { limited side effects, [67]. No } \\
\text { efficacy, [70]. }\end{array}$ \\
\hline $\begin{array}{l}\text { Microwaves } \\
\text { Thermoablation }\end{array}$ & $\begin{array}{l}\text { Microwave energy is } \\
\text { transferred into heat } \\
\text { inside the tumor. }\end{array}$ & $\begin{array}{l}\text { Microwaves antennas are positioned } \\
\text { near the tumor. The amount of heat } \\
\text { generated is more than } 43^{\circ} \mathrm{C} \text {. }\end{array}$ & $\begin{array}{l}\text { A review on the general } \\
\text { aspects of microwave } \\
\text { thermotherapies gives } \\
\text { examples of preclinical } \\
\text { trials, [71]. }\end{array}$ & $\begin{array}{l}\text { Radiofrequency ablation therapy in } \\
\text { Patients with breast cancers two } \\
\text { centimeters or less in size, [37]. } \\
100 \% \text { efficacy. Cosmesis excellent } \\
\text { in } 83 \% \text { of treated patients. }\end{array}$ \\
\hline $\begin{array}{l}\text { HIFU } \\
\text { Thermoablation }\end{array}$ & $\begin{array}{l}\text { High intensity focused } \\
\text { ultrasound energy heats } \\
\text { and destroys the tumor } \\
\text { through ablation. }\end{array}$ & $\begin{array}{l}\text { The tumor is localized by MRI or } \\
\text { ultrasound, heated by HIFU and the } \\
\text { temperature during the treatment can } \\
\text { be monitored by MRI. }\end{array}$ & $\begin{array}{l}\text { A review on the general } \\
\text { aspects of HIFU gives } \\
\text { examples of preclinical } \\
\text { trials, [72]. }\end{array}$ & $\begin{array}{l}\text { A randomized clinical trial of high- } \\
\text { intensity focused ultrasound } \\
\text { ablation for the treatment of } \\
\text { patients with localized breast } \\
\text { cancer, [44]. } \\
\text { Efficacy with complete coagulative } \\
\text { necrosis. No severe side effects. }\end{array}$ \\
\hline $\begin{array}{c}\text { LITT/ILT } \\
\text { Thermoablation }\end{array}$ & $\begin{array}{l}\text { Laser light energy is } \\
\text { transmitted to tumor } \\
\text { tissues, which heat and } \\
\text { destroy the breast } \\
\text { tumor. }\end{array}$ & $\begin{array}{l}\text { Light is produced by a laser (Nd:YAG) } \\
\text { and transported by an optical fiber, } \\
\text { which is in contact with the breast } \\
\text { tumor. Several techniques can monitor } \\
\text { the temperature during the treatment, } \\
\text { [75-77]. }\end{array}$ & $\begin{array}{l}\text { Interstitial Laser } \\
\text { hyperthermia carried out } \\
\text { on murine models with } \\
\text { liver metastases, [74]. }\end{array}$ & $\begin{array}{l}\text { A clinical trial carried out on } 232 \\
\text { female patients with liver } \\
\text { metastases from breast cancer } \\
\text { treated with laser-induced } \\
\text { interstitial thermotherapy, [73]. } \\
\text { Mean survival rate after LITT: } 4.2 \\
\text { years. }\end{array}$ \\
\hline $\begin{array}{l}\text { Magnetic } \\
\text { hyperthermia } \\
\text { (chemical } \\
\text { nanoparticles) }\end{array}$ & $\begin{array}{l}\text { Chemically synthezised } \\
\text { nanoparticles are heated } \\
\text { under the application of } \\
\text { an alternating magnetic } \\
\text { field, which produces } \\
\text { antitumor activity }\end{array}$ & $\begin{array}{l}\text { Chemically synthesised nanoparticles } \\
\text { are introduced or sent to tumors and } \\
\text { exposed to an alternating magnetic } \\
\text { field (100-200 kHz and } 10-50 \mathrm{mT}) \text {. }\end{array}$ & $\begin{array}{l}\text { Several studies describe } \\
\text { mouse treatments, [51-57] }\end{array}$ & $\begin{array}{l}\text { Clinical trials are ongoing at the } \\
\text { University of Nagoya, [78]. }\end{array}$ \\
\hline $\begin{array}{l}\text { Magnetic } \\
\text { hyperthermia } \\
\text { (biological } \\
\text { nanoparticles) }\end{array}$ & $\begin{array}{l}\text { Nanoparticles, } \\
\text { synthesized by } \\
\text { magnetotactic bacteria, } \\
\text { called magnetosomes, } \\
\text { are heated under the } \\
\text { application of an } \\
\text { alternating magnetic } \\
\text { field. }\end{array}$ & $\begin{array}{l}\text { The magnetosomes are introduced or } \\
\text { sent to tumors and exposed to an } \\
\text { alternating magnetic field (100-200 kHz } \\
\text { and } 10-50 \mathrm{mT}) .\end{array}$ & $\begin{array}{l}\text { A proof of concept of the } \\
\text { therapy on xeno-grafted } \\
\text { breast tumors has been } \\
\text { published, [57]. }\end{array}$ & No clinical trials available. \\
\hline
\end{tabular}


Table 2. Advantages and drawbacks of magnetic hyperthermia compared with other types of thermotherapy.

\begin{tabular}{|c|l|l|}
\hline Technique & \multicolumn{1}{|c|}{ Advantages } & \multicolumn{1}{c|}{ Drawbacks } \\
\hline Magnetic hyperthermia & $\begin{array}{l}\text {-A single administration in the tumor is } \\
\text { sufficient. } \\
\text {-High efficacy for low heating temperatures (43- } \\
45^{\circ} \mathrm{C} \text { ) due to intracellular heating. } \\
- \text {-Possibility to target the tumors (for example by } \\
\text { attaching to the nanoparticles an antibofdy that } \\
\text { specifically recognizes the breast tumor). } \\
\text {-Can be combined with radiotherapy, } \\
\text { chemiotherapy, surgery. }\end{array}$ & No published clinical data on breast cancer. \\
\hline $\begin{array}{c}\text { HIFU } \\
\text { LITT } \\
\text { Microwave } \\
\text { Radiofrequency }\end{array}$ & \multicolumn{1}{|c|}{ Already in clinical trials. } & $\begin{array}{l}\text {-Anti-tumor activity observed at high } \\
\text { temperatures. }\end{array}$ \\
\hline
\end{tabular}

\section{BC treatments involving hyperthermia}

In hyperthermia, the temperature of the whole or part of the organism is raised to typical temperatures of $40-43{ }^{\circ} \mathrm{C}$, (12). In this case, the antitumor activity is generated by heat. The latter produces (i) cytotoxic effects, yielding the denaturation of cytoplasmic and membrane tumor proteins, (ii) a decreases in blood flow, impairing oxygen and nutrient supply of the tumor and inducing tumor acidosis, $(12,13)$ and (iii) the activation of heat shock proteins, such as Hsp27, Hsp70 and Hsp90, which participate in the destruction of breast tumors through complex and still poorly understood mechanisms, $(14,15)$. Hyperthermia alone is not sufficient to treat BC. It is commonly used as an adjuvant and combined with other types of $\mathrm{BC}$ treatments such as chemotherapy, radiotherapy, targeted therapy and cryotherapy, (16-19).

Hyperthermia is combined with radiations to either treat localized recurrent $\mathrm{BC}$ of advanced stages $(20,21,23-27)$ or, more rarely, primary tumors, (22). In this case, patients first receive a dose of radiation of typically 8 to 32 Gy for recurrent breast tumors that have previously been treated by radiotherapy $(20,21$, 24) or a dose of 60-70 Gy for superficial breast tumors treated for the first time, (22). It is usually not possible to exceed these radiation doses without causing life threatening conditions for the patients. It does however happen, specifically for BC of advanced stages, that these radiation doses are not sufficient to completely eradicate BC. In this case, hyperthermia can be carried out after radiations, for example by increasing the tumor temperature to $40-44{ }^{\circ} \mathrm{C}$ for about an hour, (20-23). The efficacy of a treatment combining radiotherapy and hyperthermia was demonstrated in a series of clinical trials, which showed that the percentage of complete BC remission increases from $44 \%$, (20), or $41 \%$, (23), using radiotherapy alone to $70 \%$, (20), or $59 \%$, (23), using radiotherapy and hyperthermia.
Hyperthermia can also be combined with chemotherapy, for example to treat metastatic breast tumors. It was shown that combining whole or part body hyperthermia with chemotherapy increases the efficacy of chemotherapy, (29). A few studies also report the use of hyperthermia combined with both radiotherapy and chemotherapy for the treatment of recurrent localized recurrent $\mathrm{BC},(31,32,33)$. For a patient with local metastases, where radiotherapy and chemotherapy were inefficient, the addition of hyperthermia at $38-41^{\circ} \mathrm{C}$ led to the disappearance of the tumor, (31). In two other studies, this combination of treatments using drugs such as epirubicin and ifosfamide, (32), or liposomal doxorubicin, (33), led to $20 \%$ total remission of recurrent localized BC, (33). Targeting therapy using HER-2 may also be combined with hyperthermia. For example, a system was used for drug delivery, which contained thermosensitive liposomes with HER-2 targeting molecules located at their surface, (30). This thermosensitive liposome delivered the antitumor drugs that it contained specifically at the breast tumor location after an increase of the tumor temperature to $39-41{ }^{\circ} \mathrm{C}$, which enabled the release of the drugs specifically to the breast tumors.

Finally, hyperthermia was also used in combination with cryotherapy. The efficacy of this combined treatment was shown for the treatment of a large metastatic breast tumor of $12 \mathrm{~cm}$ in diameter, which could not successfully be treated by cryosurgery alone but disappeared completely when cryosurgery was combined with hyperthermia, (34).

Hyperthermia was generated in several different ways using a microwave applicator operating at 433 $\mathrm{MHz}(18,21,24)$, a Sigma 60 applicator for part body hyperthermia, (26), or a radiant system for whole body hyperthermia, (28). With a radiant system, a temperature of $42{ }^{\circ} \mathrm{C}$ can be maintained throughout the whole body during an hour. Other hyperthermia systems include the Aquatherm and Iratherm systems 
in which heating is induced by far-infrared radiations, which heat the blood under the skin and gradually heat the whole body in 60-90 minutes.

\section{Treatments of breast cancer by thermo- ablation}

In thermal ablation, the tumor temperature is raised above $43^{\circ} \mathrm{C}$, resulting in larger cytotoxic effects than in hyperthermia and in the direct destruction of the breast tumor. Since thermal ablation alone is usually sufficient to destroy breast tumor tissues, it is often not combined with other types of BC treatments. Thermoablation enables to treat localized breast tumors of small sizes (2 to $6 \mathrm{~cm}),(35-37,39-47)$ and more rarely metastatic liver tumors originating from $\mathrm{BC}$, (38). During the treatment, the tumor temperature is typically raised to $90-95{ }^{\circ} \mathrm{C}$ during 10 to 15 minutes using radiofrequencies, $(35,37)$, or to $46-50^{\circ}$ during 60 seconds using microwaves, (38), to $60-90{ }^{\circ} \mathrm{C}$ during one to two hours using high intensity focused ultrasound (HIFU), $(44,45)$, or to $48{ }^{\circ} \mathrm{C}$ during 30 minutes using interstitial laser thermotherapy (ILT or LITT), (48). The heat can be produced by different types of equipment, such as an RF 460 monopolar electrosurgical generator from RITA Medical system, $(35,37)$, a JC200 from Chongqing Haifu Technology, (42, 43), a microwave coagulator operating at $2.45 \mathrm{GHz},(38)$, or a Yag: ND pulsed laser, (48), for radiofrequency, HIFU, microwave and LITT thermotherapies, respectively. Magnetic resonance temperature imaging (MRTI), ultrasound or ultrasonography can be used to measure the tumor temperature during the treatment and to try to prevent overheating of healthy tissues, (44). MRTI provides an estimate of the temperature by measuring the molecular diffusion coefficient, the longitudinal relaxation time T1 or the proton resonance frequency of tissue water, which depends on water, (49). Ultrasounds and ultrasonography measure the echo shifts due to changes in tissue thermal expansion and speed of sound, the variation in the attenuation coefficient or the change in backscattered energy from tissue inhomogeneity, (50). These treatments have shown efficacy. For example, using microwaves, it was possible to destroy $100 \%$ of breast tumors, (38). Clinical trials on BC involving HIFU also led to the complete (or almost complete) disappearance of breast tumors, (42). However, these thermotherapies possess a drawback, which comes from the high temperatures, which are needed to achieve high efficacy. Without a method to predict and measure accurately these temperatures, the latter can result in side effects, including the destruction of healthy tissues.
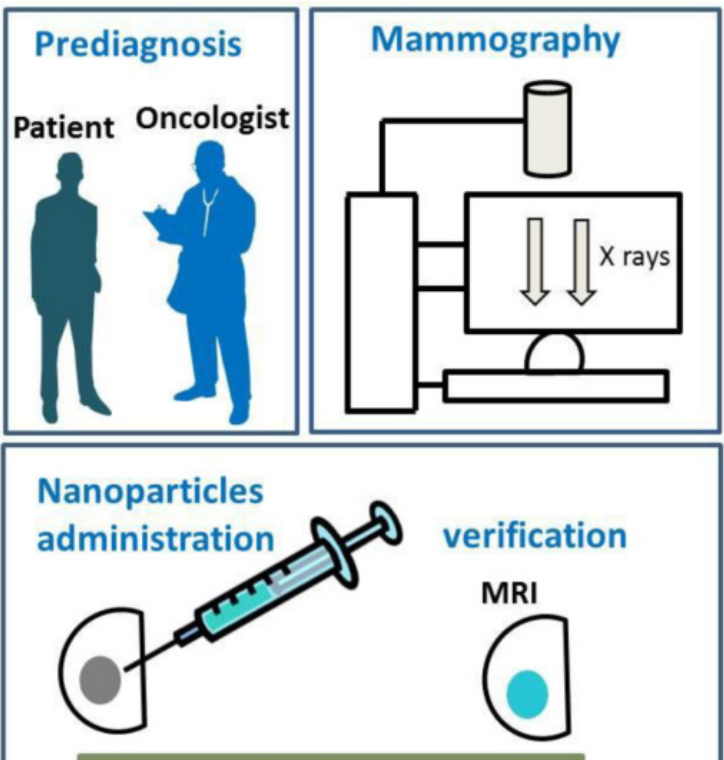

Targets exclusivly tumor tissues

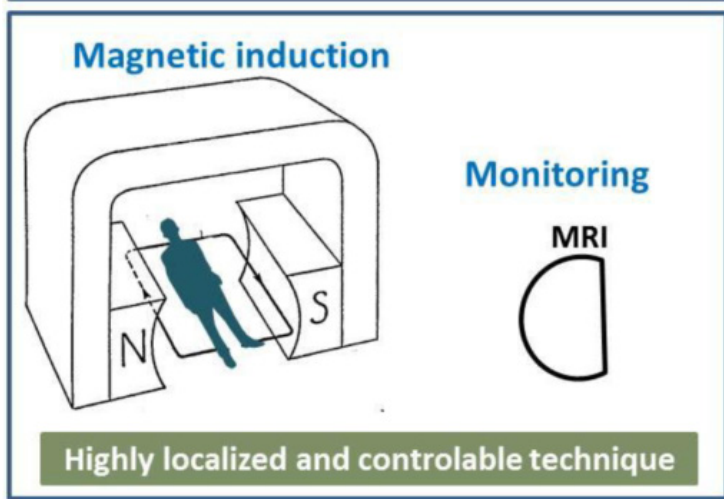

Figure I. Schematic diagrams showing the different steps of a typical treatment involving magnetic hyperthermia.

\section{Magnetic hyperthermia}

In magnetic hyperthermia, nanoparticles are administrated (or sent) to tumors and heated under the application of an alternating magnetic field. The heat produced by the nanoparticles induces anti-tumor activity. The advantages of magnetic hyperthermia compared with the other heating techniques described above come from: (i), the cellular internalization of the nanoparticles under the application of an alternating magnetic field, which yields more efficient tumor destruction than extracellular heating usually achieved with the other heating methods, (57-60), (ii), the possibility to target the tumors, for example by attaching to the nanoparticles molecules that specifically recognize the cancer cells and, (iii), the fine temperature tuning that can be achieved by accurately selecting the strength or intensity of the applied alternating magnetic field and the quantity of nanoparticles administered, (iv), the very localized heat that shall prevent damaging healthy tissues surrounding 
the tumor. Two different types of nanoparticles have been tested for magnetic hyperthermia treatment of BC, chemically synthesized nanoparticles, which are the most frequently studied, and biologically produced nanoparticles, synthesized by magnetotactic bacteria, called magnetosomes.

Usually, chemically synthesized nanoparticles used to carry out magnetic hyperthermia on BC are small, typically less than $20 \mathrm{~nm}$, made of maghemite or magnetite and superparamagnetic, which means that they possess a thermally unstable magnetic moment, (51-56). Magnetic hyperthermia has successfully been tested on breast tumors xeno-grafted under the skin of mice. For that, 1 to $2 \mathrm{mg}$ of nanoparticles, (51-53), have been administered either intravenously, $(51,52)$, or directly to tumors, (53), of typical sizes 100 to $200 \mathrm{~mm}^{3},(51,52)$. Specific targeting of the tumors was achieved by using 111InCh antibody, $(51,52)$, or anti-HER2 molecules attached either to the nanoparticles, (53-55), or to the liposomes containing the nanoparticles, (56). In order to generate heat, the nanoparticles were exposed to an alternating magnetic field of strength 12-130 mT and frequency of 118-360 $\mathrm{kHz}$ during 20-30 minutes, (51-56). The efficacy of these preclinical treatments was revealed by the disappearance of the tumors, (51-56). Clinical trials using magnetic hyperthermia are ongoing at the University of Nagoya to treat BC. Figure 1 shows the different steps, which may be involved in the treatment of $B C$

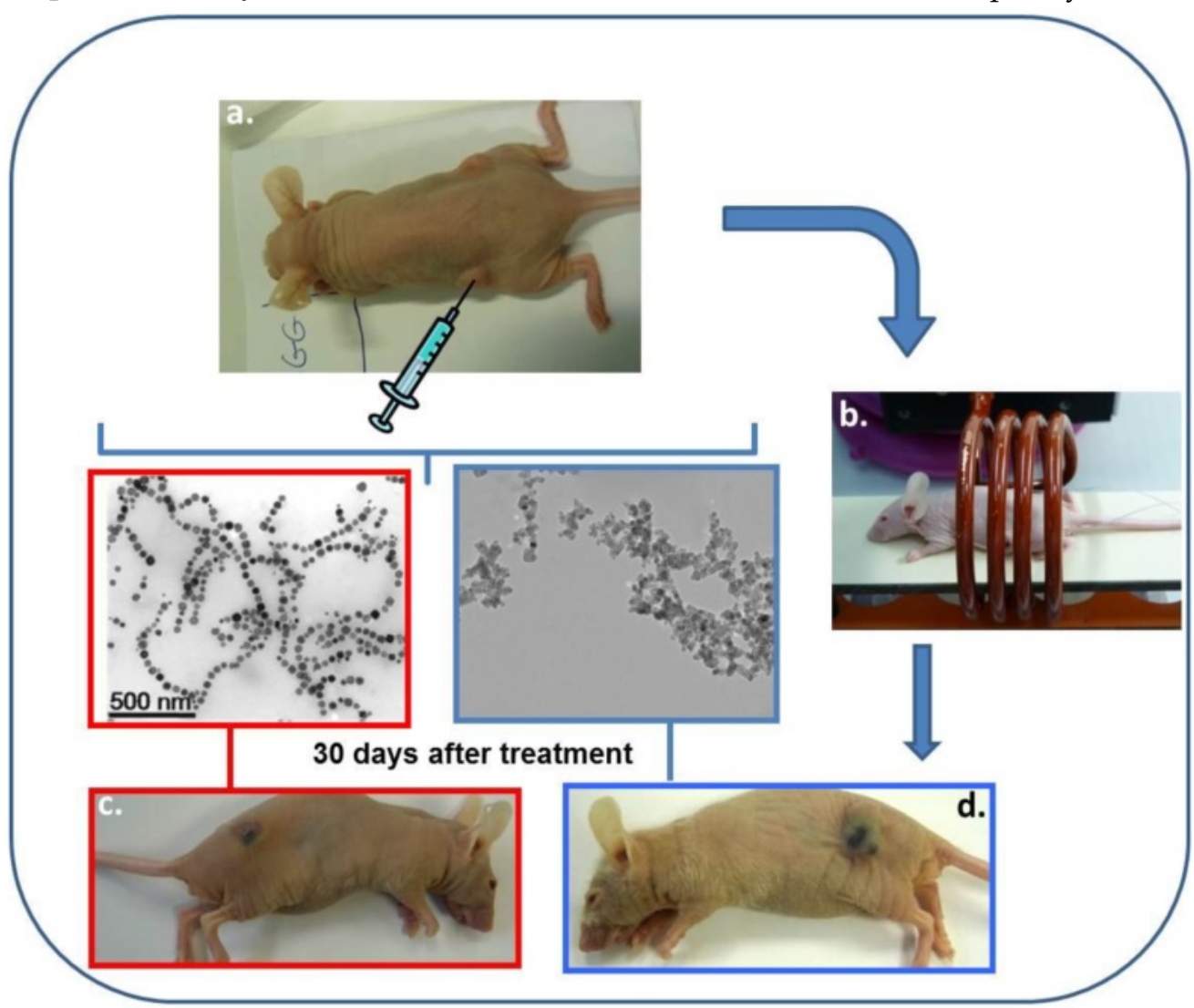

using magnetic hyperthermia. Breast tumor may first be diagnosed using mammography. The nanoparticle suspension may then be administered to the breast tumor using a syringe. MRI may be used to visualize the nanoparticles during and after the administration of the nanoparticle suspension and to verify the correct location of the nanoparticles in the tumor before and during the treatment. After that, the patient may be positioned inside an instrument that generates an alternating magnetic field and heats the nanoparticles contained in the tumor. After treatment, the variation of the tumor size may be followed by MRI.

In order to increase the amount of heat delivered, nanoparticles synthesized by magnetotactic bacteria, called magnetosomes, which are usually larger, with average sizes lying between 40 and 60 $\mathrm{nm}$, better crystallized and which possess a more stable magnetic moment than chemically synthesized nanoparticles, (57-65), have been tested preclinically for BC treatment, (57-60). Figure 2 illustrates the experimental protocol, which was used during the treatment of the mice. Shortly, $100 \mu$ of a suspension containing $1 \mathrm{mg}$ of chains of magnetosomes, extracted from magnetotactic bacteria and mixed in water, was administered to MDA-MB-231 breast tumors xeno-grafted under the skin of mice. The mice were then exposed three times during twenty minutes to an alternating magnetic field of average field strength 20 $\mathrm{mT}$ and frequency $198 \mathrm{kHz}$. The treatment led to the complete disappearance of the tumor in several mice 30 days after the treatment as shown in Figure 2, (57).

Figure 2. A series of Figures showing the different steps of a treatment of MDA-MB-23I breast tumors xeno-grafted under the skin of a mouse using magnetic hyperthermia. The nanoparticle suspensions are first administered to the tumors, (a). The mouse is then positioned inside a coil that generates an alternating magnetic field of average field strength 20 $\mathrm{mT}$ and frequency $198 \mathrm{kHz}$ to heat the nanoparticle contained in the tumors, (b). The treatment results in the disappearance of the tumor using the magnetosomes, (c), while it does not destroy the tumor using chemically synthesized nanoparticles, (d). 
For the mice, which were treated in the same way, but with a suspension containing $1 \mathrm{mg}$ of chemically synthesized nanoparticles instead of the magnetosome, the treatment was inefficient and the tumor was still there 30 days following the beginning of the treatment as shown in Figure 2. It was therefore demonstrated that the magnetic hyperthermia treatment of $\mathrm{BC}$ was more efficient using magnetosomes than two types of chemically synthesized nanoparticles (SPION covered with PEG or citrate molecules) both in vivo on MDA-MB231 tumors and in vitro on MDA-MB231 cells and hella cells, (57) .

The physical mechanisms, procedures, pre-preclinical and clinical data, available on each of the different types of thermotherapy are summarized in table 1.

\section{Conclusion}

In conclusion, two types of thermotherapies, hyperthermia that is usually combined with other commonly used BC treatments, and thermoablation, which is often used alone, have been described. The results obtained with an emerging thermotherapy, called magnetic hyperthermia, in which magnetic nanoparticles are heated inside tumors under the application of an alternating magnetic field, have also been presented. The advantages and drawbacks of magnetic hyperthermia compared with the other thermotherapies are summarized in table 2 . In practice, hyperthermia may essentially be used for the treatment of recurrent localized breast tumor of stages III and IV, while thermoablation may be carried out on small localized tumors. Since hyperthermia and thermoablation have both shown efficacy, there is no reason why they should not be used more frequently for the treatment of these indications. Magnetic hyperthermia is a promising thermotherapy, but research still needs to be carried out on several aspects such as the specific targeting of the tumor by the nanoparticles, the control of the heat released by the nanoparticles and the nanoparticle toxicity in order to be able to use it routinely for BC treatment.

The cost of breast cancer is about 30 billion $\$$ a year, with $30 \%$ and $50 \%$ of this cost being attributed to productivity loss and medical costs respectively. The loss in productivity and medical costs can be minimized by developing new, improved and less expensive treatments, such as those described in this review.

\section{Methods used for the literature search}

Pubmed, medline, google, google scholar and clinicaltrials.gov were used for the literature search with keywords such as: thermotherapy, hyperthermia, thermoablation, magnetic hyperthermia, breast cancer, breast tumor.

\section{Competing Interests}

The authors have declared that no competing interest exists.

\section{References}

1. General information about breast cancer. www.breastcancer.org, www.nationalbreastcancer.org, www.cancer.gov/cancertopics/types/breast, www.breastcancercare.org.uk.

2. Cindy B, Matsen MD, Leigh A, et al. Breast Cancer: A Review for the General Surgeon. JAMA 2013; 148: 971-980.

3. Tinoco G, Warsch S, Gluck S, et al. Treating Breast Cancer in the $21^{\text {st }}$ Centrury: Emerging Biological Therapies. J Cancer 2013; 4: 117-132.

4. [Internet] Document published on the website of the centers for Disease Control and Prevention. http://www.cdc.gov/nchs/data/hus/hus12.pdf.

5. Zackrisson S, Andersson I, Janzon L, et al. Rate of over-diagnosis of breast cancer 15 years after end of Malmö mammographic screening trial: follow-up study. BMJ 2006; 332: 689-693.

6. [Internet] Document describing the intrabeam therapy. http://www.meditec.zeiss.com/intrabeam.

7. [Internet] Website of the mammosite company. http://www.mammosite.com.

8. Kapp DS, Barnett TA, Cox RS, et al. Hyperthermia and radiation therapy of local-regional recurrent breast cancer: prognostic factors for response and local control of diffuse or nodular tumors. Int. J. Radiat. Oncol. Biol. Phys. 2008, 20: 1147-64.

9. Higgins MJ, and Baselga J. Targeted therapies for breast cancer. The J. Clin. Investigation 2011, 121: 3797-3803

10. Nuti M, Bellati F, Visconti V, et al. Immune Effects of Trastuzumab. J Cancer 2011, 2: 317-323.

11. Two websites with information concerning clinical trials on BC. www.clinicaltrials.gov, www.breastcancertrials.org.

12. Hilderbrandt $B$, Wust $P$, Ahlers $O$, et al. The cellular and molecular basis of hyperthermia. Critical Reviews in Oncology/Hemathology 2002, 43: 33-56.

13. Chichel A, Skowronek J, Kubaszewska M, et al. Hyperthermia - description of a method and a review of clinical applications. Radiotherapy 2007, 12: 267-275.

14. Barnes JA, Dix DJ, Collins BW, et al. Expression of inducible HsP70 enhances the proliferation of MC-7 breast cancer cells and protects against the cytotoxic effects of hyperthermia. Cell Stress and Chaperones 2001, 6: 316-325.

15. Braiden V, Ohtsuru A, Kawashita Y, et al. Eradication of Breast Cancer Xenografted by Hyperthermic Suicide Gene Therapy under the Control of the Heat Shock Protein Promoter. Human Gene Therapy 2000, 11: 2453-2463.

16. Perez CA, Pajak T, Enami B, et al. Randomized phase III study comparing irradiation and hyperthermia with irradiation alone in superfical measurable tumors: final report by the Radiation Therapy Oncology Group. Am. J. Clin. Oncol. 1991, 14: 133-141.

17. Vernon C, Hand JW, Field SB, et al. Radiotherapy with or without hyperthermia in the treatment of superficial localized breast cancer: results from five randomized controlled trials. Int. J. Oncol. Biol. Phys. 1996, 35: 731-744.

18. Chinel C, Skowronek J, Kubaszewska M, et al. Hyperthermia-description of a method and a review of clinical applications. Rep. Pract. Oncol. Radiother. 2007, 12: 267-275.

19. Kim JH, Hahn GM, Carlon RW. Combination hyperthermia and radiation therapy for malignant melanoma. Cancer 1982, 50: 478-482.

20. Gonzalez DG, Van Dijk JDP, Blank LECM. Chestwall recurrences of breast cancer: Results of combined treatment with radiation and hyperthermia. Radiology and Oncology 1988, 12: 95-103.

21. Linthorst M, Van Geel AN, Baaijens M, et al. Re-irradiation and hyperthermia after surgery for recurrent cancer. Radiotherapy and Oncology 2013; doi: 10.1016/j.radonc.2013.05.010.

22. Jones EL, Oleson JR, Prosnitz LR, et al. Randomized Trial of Hyperthermia and Radiation for Superficial Tumors. J. clinical oncology 2005, 23: 3079-3085.

23. Vernon CC, Hand JWH, Field SB, et al. Radiotherapy with or without hyperthermia in the treatment of superficial localized breast cancer: results from five randomized controlled trials. Int. J. Radiation Oncology 1996, 35: 731-744.

24. Zee J, Treurniet-Donker AD, The SK, et al. Low dose reirradiation in combination with hyperthermia: a palliative treatment for patients with breast cancer recurring in previously irradiated areas. Int. J. Radiation Oncology Biol. Phys. 1988, 15: 1407-1413.

25. Kapp DS, Barnett TA, Cox RS, et al. Hyperthermia and radiation therapy of loco-regional recurrent breast cancer: prognostic factors for response and local control of diffuse or nodular tumors. Int. J. Radiation Oncology Biol. Phys. 1991, 20: 1147-1164.

26. Yokoyama G, Fujii T, Ogo E, et al. Advanced chemoresistant breast cancer responding to multidisciplinary treatment with hyperthermia, radiotherapy, and intraarterial infusion. Int. J. Clin. Oncol. 2005, 10: 139-143.

27. Zagar TM, Oleson JR, Vujaskovic Z, et al. Hyperthermia for locally advanced breast cancer. Int. J. Hyperthermia 2010, 26: 618-624.

28. Wust P, Hildebrandt B, Sreenivasa G, et al. Hyperthermia in combined treatment of cancer. The Lancet Oncology 2002, 3: 487-497.

29. [Internet] Identifier: NCT 00003135. http://www.clinicaltrials.gov. 
30. Kullberg M, Mann K, Owens JL. A two-component drug delivery system using HER-2 targeting thermosensitive liposomes. J. Drug Targeting 2009; 17: 98-107.

31. Yamamoto D, Inui $\mathrm{T}$, Tsubota $\mathrm{Y}$, et al. The utility of hyperthermia for local recurrence of breast cancer. World Journal of Surgical Oncology 2012, 10: 1-3.

32. Feyerabend T, Wiedemann GF, Jäger B, et al. Local hyperthermia, radiation, and chemotherapy in recurrent breast cancer is feasible and effective except for inflammatory disease. Int. J. Radiation Oncology Biol. Phys. 2001, 49: 1317-1325.

33. Kouloulias VE, Dardoufas CE, Kouvaris JR, et al. Liposomal doxorubicin in conjunction with reirradiation and local hyperthermia treatment in recurrent breast cancer: a phase I/ II trial. Clin. Cancer Res. 2002, 8: 374-82.

34. Hachisuka J, Doi K, Furuea M. Combination cryosurgery with hyperthermia in the management of skin metastasis from breast cancer: A case report. Int. J. Surg. Case Rep. 2012, 3: 68-69.

35. Fornage BD, Snelge N, Ross MI, et al. Small $(<2 \mathrm{~cm})$ breast cancer treated with US-guided radiofrequency ablation: feasibility study. Radiology 2004, 231: 215-224.

36. Hayashi A, Silver SF, Westhuizen NG, et al. Treatment of invasive breast carcinoma with ultrasound-guided radiofrequency ablation. The American Journal of Surgery. 2003, 185: 429-435.

37. Oura S, Tamaki T, Hirai I, et al. Radiofrequency ablation therapy in patients with breast cancers two centimeters or less in size. Breast Cancer 2007, 14: $48-54$

38. Abe H, Kurumi Y, Naka S, et al. Open-Configuration MR-Guided Microwave Thermocoagulation Therapy for Metastatic Liver Tumors from Breast Cancer. Breast Cancer 2005, 12: 26-31.

39. Sun Y, Zheng Y, Ran H, et al. Superparamagnetic PLGA-iron oxide microcapsules for dual-modality US/MR imaging and high intensity focused US breast cancer ablation. Biomaterials 2012, 33: 5854-5864.

40. Wu F, Wang ZB, Cao Y-De, et al. A randomized clinical trial of high-intensity focused ultrasound ablation for the treatment of patients with localized breast cancer. British J Cancer 2003, 89: 2227-2233.

41. Huber PE, Jenne JW, Rastert R, et al. A new noninvasive approach in breast cancer therapy using magnetic resonance imaging-guided focused ultrasound surgery. Cancer research 2001, 61: 8441-8447.

42. Wu F, Wang ZB, Zhu H, et al. Extracorporal high intensity focused ultrasound treatment for patients with breast cancer. Breast Cancer Research and Treatment 2005, 92: 51-60.

43. Wu F, Wang ZB, Cao YDC, et al. "Wide local ablation" of localized breast cancer using high intensity focused ultrasound. J. Surgical Oncology 2007, 96: 130-136.

44. [Internet] Insightec. www.insightec.com.

45. Hilger I, Hergt R, Kaiser WA. Use of magnetic nanoparticle heating in the treatment of breast cancer. IEE Proc. Nanobiotechnol 2005, 152: 33-39.

46. Akimov AB, Seregin VE, Rusanov KV, et al. Nd:YAG interstitial laser thermotherapy in the treatment of breast cancer. Lasers in surgery and medicine 1998, 22: 257-267.

47. Milne PJ, Parel JM, Manns F, et al. Development of stereotactically guided laser interstitial thermotherapy of breast cancer: In situ measurement and analysis of the temperature field in ex vivo and in vivo adipose tissue. Lasers in surgery and medicine 2000, 26: 67-75.

48. Haraldsdóttir KH, Ivarsson K, Götberg S, et al. Interstitial laser thermotherapy (ILT) of breast cancer. Eur. J. Surg. Oncol. 2008, 34: 739-745.

49. Quesson B, Zwart JA, Moonen CTW. Magnetic resonance temperature imaging guidance of thermotherapy. J. Magn. Res. Imag. 2000, 12: 525-533.

50. Arthur RM, Straube WL, Trobaugh JW, Moros EG. Non-invasive estimation of hyperthermia temperatures with ultrasound. Int. J. Hyperthermia 2005, 21: 589-600.

51. DeNardo SJ, DeNardo G, Miers LA, et al. Development of Tumor Targeting Bioprobes (111In-Chimeric L6 monoclonal antibody nanoparticles) for alternating magnetic field cancer therapy. Clin. Canccer Res. 2005, 11: 7087s-7092s.

52. DeNardo SJ, DeNardo GL, Natarajan A, et al. Thermal dosimetry predictive of efficacy of ${ }^{111} \mathrm{In}$-ChL6 nanoparticle AMF-induced thermoablative therapy for human breast cancer in mice. The J Nuclear Medicine 2007, 48: 437-444.

53. Kikumori T, Kobayashi T, Sawaki M, et al. Anti-cancer effect of hyperthermia on breast cancer by magnetite nanoparticle-loaded anti-HER2 immunoliposomes. Breast Cancer Res. Treat. 2009, 113: 435-441.

54. Mi Y, Liu X, Zhao J, et al. Multimodality treatment of cancer with herceptin conjugated thermomagnetic iron oxides and docetaxel loaded nanoparticles of biodegradable polymers. Biomaterials 2012, 33: 7519-7529.

55. Zhang J, Dewilde AH, Chinn P, et al. Herceptin-directed nanoparticles activated by an alternating magnetic field kill HER-2 positive human breast cells in vitro via hyperthermia. Int. J. Hyperthermia 2011, 27: 682-697.

56. Ito A, Kuga $\mathrm{Y}$, Honda $\mathrm{H}$, et al. Magnetite nanoparticle-loaded anti-HER2 immunoliposomes for combination of antibody therapy with hyperthermia. Cancer Letters 2004, 212: 167-175.

57. Alphandéry E, Faure S, Seksek O, et al. Chains of magnetosomes extracted from AMB-1 magnetotactic bacteria for application in alternative magnetic field cancer therapy. ACS Nano 2011, 5: 6279-6296.

58. Alphandéry E, Chebbi I, Guyot F, et al. Use of bacterial magnetosomes in the magnetic hyperthermia treatment of tumours: A review. Int. J. Hyperthermia 2013, DOI: $10.3109 / 02656736.2013 .821527$.
59. Alphandéry E. Applications of magnetosomes synthesized by magnetotactic bacteria in medicine. Frontiers in Bioengineering and biotechnology 2014, DOI: 10.3389 /fbioe.2014.00005

60. Alphandéry E, Guyot F, Chebbi I. Preparation of chains of magnetosomes, isolated from Magnetospirillum magneticum strain AMB-1 magnetotactic bacteria, yielding efficient treatment of tumors using magnetic hyperthermia. Int. J. Pharmaceutics 2012, 434: 444-452.

61. Alphandéry E, Amor M, Guyot F, et al. The effect of iron-chelating agents on Magnetospirillum magneticum strain AMB-1: stimulated growth and magnetosome production and improved magnetosome heating properties. Appl. Microbiol. Biotechnol 2012, 96: 663-670.

62. Alphandéry E, Faure S, Raison L, et al. Heat production by bacterial magnetosomes exposed to an oscillating magnetic field. J. Phys. Chem. C 2011, 115: 18-22.

63. Alphandéry E, Carvallo C, Menguy N, et al. Chains of cobalt doped magnetosomes extracted from AMB-1 magnetotactic bacteria for application in alternative magnetic field cancer therapy. J. Phys. Chem. C 2011, 115: 11920-11924.

64. Alphandéry E, Lijeour L, Lalatonne Y, Motte L, et al. Different signatures between chemically and biologically synthesized nanoparticles in a magnetic sensor: A new technology for multiparametric detection. Sensors and Actuators B 2010, 147: 786-790.

65. Bazylinski DA, Frankel RB. Magnetosome formation in prokaryotes. Nature Reviews Microbiology 2004, 2: 217-230.

66. Stang J, Haynes M, Carson P, Moghaddam M. A preclinical system prototype for focused microwave thermal therapy of the breast. IEEE Trans Biomed. Eng. 2012, 59: 2431-2438.

67. Santoro G, Avossa M, Della Corte M. Radiofrequency thermoablation in locally advanced breast cancer. Breast 2012, 4: 601-6013.

68. Garbay J-R, Mathieu M-C, Lamuraglia M, Lassau N, Balleyguier C, Rouzier R. Radiofrequency Therma Ablation of Breast Cancer Local Recurrence: A Phase II Clinical Trial. Annals of Surgical Oncology 2008, 15: 3222-3226.

69. Udagawa Y, Nagasawa H, Kiyokawa S. Inhibition by whole-body hyperthermia with far-infrared rays of the growth of spontaneous mammary tumours in mice. Anticancer research 1999, 19: 4125-4130.

70. Ni Y, Mulier S, Miao Y, Michel L, Marchal G. A review of the general aspects of radiofrequency ablation. Abdominal Imaging 2005, 30: 381-400.

71. Ryan T P, Turner P F, Hamilton B, Interstitial microwave transition from hyperthermia to ablation: Historical perspectives and current trends in thermal therapy. Int. J. Hyperthermia 2010, 26: 415-433.

72. Kennedy J E, Haar G R, Cranston D. High intensity focused ultrasound: surgery of the future? British Journal of Radiology 2003, 76: 590-599.

73. Mack M G, Straub R, Eichler K, Sollner O, Lehnert T, Vogl T J. Breast Cancer Metastases in Liver: Laser-induced Intersitial Thermotherapy-Local Tumor Control Rate and Survival Data. Radiology 2004, 233: 400-409.

74. Muralidharan V, Nikfarjam M, Malcontenti-Wilson C, Christophi C. Interstitial Laser Hyperthermia and the Biological Characteristics of Tumor: Study of Murine Model of Colorectal liver metastases. Journal of Clinical Laser Medicine and Surgery 2003, 21: 75-83.

75. Schena E, Saccomandi P, Giurazza F, Caponero M A, Mortato L, Di Matteo FM, Del Vescovo R, Beomonte Z B, Silvestri S. Experimental assessment of CT-based thermometry during laser ablation of porcine pancreas. Phys. Med. Biol. 2013, 58: 5705-5716

76. Saccomandi $\mathrm{P}$, Schena E, Silvestri S. Techniques for temperature monitoring during laser-induced thermotherapy: an overview. Int. J. Hyperthermia 2013, 29: 609-619.

77. Bruners P, Levit E, Penzkofer T, Isfort P, Ocklenburg C, Schmidt B, Schmitz-Rode T, Günther RW, Mahnken AH. Multi-slice computed tomography: A tool for non-invasive temperature measurement? Int. J. Hyperthermia 2010, 26: 359-365.

78. [Internet] Webpage. http://www.nanotech-energy.net/attachments/File/ 06-68.pdf. 